\title{
Könyvismertető
}

\section{Tari Annamária: Online illúzió - offline valóság c. könyvéröl}

Tari Annamária új könyvvel jelentkezett. A megszokott stílusban és koncepcióval, mégis új (és mindig megújuló) tartalommal tárja elénk a fiatal generáció életének meghatározó tényezőit, sok esetben nehezen érthető magatartásának magyarázatát egy klinikai szakpszichológus szemszögéből.

A fiatal generáció sok szempontból élvezi a szakértők fokozott figyelmét. A cégek a jövő fogyasztóit látják bennük, a kutatók a korábbi generációkhoz képest megváltozott magatartásukat próbálják megérteni, az oktatásban pedig a célközönség állandó megnyeréséért és figyelmének fenntartásáért folyik a küzdelem, óráról órára. A marketing szakma hagyományosan szívesen támaszkodik más tudományterületek ismereteire, így ajánlatos e kötetet is bevenni a források tárházába, mivel hasznos ismereteket ad a fiatal generációk lelki müködéséröl, problémáiról, meghatározó élethelyzeteiröl. Ahogy egyébként Tari Annamáriát is inspirálták a marketing szakirodalom jeles munkái, így remélhető, hogy a marketing szakma müvelői is kiváló forrásként tekintenek a munkára az új életviszony megismeréséhez. A szerző a kötet megírásához hazai és nemzetközi szakértők és kutatók eredményeire támaszkodik, amely forrásokat az olvasó is követni tud a megfejelő hivatkozásuk révén.

Tari Annamária új kötete ma még inkább aktuálissá vált. A koronavírus terjedése és a hétköznapi életre, a gazdaság és társadalom egészére gyakorolt hatásaival jelentősen megváltozott a körülöttünk lévő világ üteme, következésképpen a fogyasztási és vásárlási szokások. Az életterünk platformjai jelentősen átalakultak. Az online tér erősödése új lendületet kapott, ami a fiatalok gondolkodására és magatartására is bizonyára fokozottan kifejti hatását. Ezért ma különösen fontos, hogy megértsük a digitális világunk magatartásunkra gyakorolt hatásait a fiatalok, vagy akár a szülők, az idősebbek életében.

A könyv 10 történeten, szituáción keresztül mutatja be a vignetta módszer alkalmazásával a mai gyerekek és fiatalok életét és annak kihívásait. Az élvezetesen megírt felvezető szituációk egyediségéből kiindulva mutat rá a szerző az általános összefüggésekre. Az alábbi összefoglalás egy rövid áttekintést kíván adni a tartalomból, azzal a korláttal, hogy kétségtelenül nem tudja visszaadni a szerző érdekes esetleírásait, azzal kapcsolatos eszmefuttatásait.

Az első történetben egy ötéves kisgyerek és a digitális eszközök használatának konfliktusait ismerjük meg a szülők szemszögéből. A szakértő egyértelműen a mellett foglal állást, hogy a gyerekek esetén a minél későbbi eszközhasználatra kell a szülöknek törekedniük.

A második történetben a pályaválasztás előtt elbizonytalanodó fiatalokról kapunk képet, és arról, hogy az ebből adódó családi konfliktusok miként vetnek árnyékot e korosztály egzisztenciális elöre lépésében.

A harmadik szituáció egy kamasz önképének konfliktusait láttatja, és azt, milyen hatásai vannak a kortársaknak és a közösségi platformok a fiatalok bizonyítási kényszerének kialakulásában, az önkép alakulásában és annak rendellenes fejlődésében.

A negyedik fejezet a fiatalok széles körére jellemző mamahotel jelenséget mutatja be, és a munka világában való elindulást akadályozó kapunyitási pánikot. Látjuk, hogy miként azonosulnak az azonnali eredményeket ígérő lehetőségekkel, és milyen könnyen vetik bele magukat a fogyasztás örömeibe. Kétségtelen azonban, amiben csak egyet tudunk érteni a szakértővel, hogy az élet kihívásai (és nehézségei) részén szerzett tapasztalatok előbb-utóbb egyensúlyt hoznak.

Az ötödik fejezet arra a jelenségre hívja fel a figyelmet, miszerint a fiatal generáció jelentősen eltérő módon viszonyul a tudásszerzéshez, mint a korábbi generációk. A fiatalok más módon tájékozódnak, szerzik ismereteiket, ezeket más súlyokkal is látják el, másfajta eszközök állnak rendelkezésükre, ami jelentős következményekkel járhat a gazdaság különböző szféráiban a számukra rendelkezésre álló lehetőségekben, a helyük megtalálásában.

A hatodik egység a tanárok által tapasztalt kihívásokat és a tanítás megváltozott körülményeit mutatja be. A szakértő egyrészt nagy empátiával fordul a tanárok felé, megértve azt is, ha valaki a kiégés határára kerül az iskolákban folyó mindennapi küzdelmek hatására. Ugyanakkor empátiára bíztat mindenkit is: meg kell értenünk a fiatalok más müködését, viselkedésmintáit, és elfogadni, hogy ezeket nem ők választották, csupán beleszülettek egy megváltozott világba.

A hetedik történet olyan fiatalokról szól, akik párkapcsolati konfliktusaikat és csalódásaikat tárgyalják meg egymással, illetve arról, hogy ezeket az élethelyzeteket miként befolyásolja az online tér és az állandó virtuális jelenlét érzelmeket alakító hatásmechanizmusa. A szakértő határozottan felhívja a figyelmet a virtuális jelenlét korlátozására, határainak megszabására. 
A nyolcadik történet az online térben fogyasztott tartalmak révén szerzett agresszió, illetve agresszív hajlamok fontosságára, alig érzékelhető kialakulására hívja fel a figyelmet. A szakértő ebben a kontextusban is nyomatékosítja, hogy számos körülmény vezet a mai fiatal generáció elbizonytalanodásához, köztük a versenyhelyzet éleződéséhez, az újfajta értékek kialakulásához.

A kilencedik egység egy fiatal párkapcsolati nehézségei bemutatásával - a szülők elbeszélése alapján mutatja be az online létben az azonnaliság felértékelödésének következményeit, ebből következően pedig a gyorsan megélt érzelmeknek és azok feldolgozásának hiánya következtében kialakuló emocionális kiégés súlyát.

A tizedik szituáció két Insta-generációs fiatal párbeszédét eleveníti meg. Párbeszédükkel a szakértő arra hívja fel a figyelmet, miként élik meg a fiatalok a verseny gyorsuló ütemét, hogyan kerül előtérbe számukra a sikeresség vágya, és milyen következményei látszónak a virtuális térben kialakuló paraszociális kapcsolatok térnyerésének.

Tari Annamária könyve lebilincselő olvasmány értékes szakértői eszmefuttatásokkal, amit minden olyan szakmabeli számára csak ajánlani tudok, aki a fiatalok magatartását, gondolkodását, az életükben felmerülő nehézségeket szeretné megérteni.

Dr. Jakopánecz Eszter Pécsi Tudományegyetem 